\title{
Faktor Adopsi Layanan E-Government Jenis Layanan Transaksi
}

\author{
Rahadian Bisma ${ }^{1}$ \\ ${ }^{1}$ Teknik Informatika - Universitas Negeri Surabaya \\ 1Rahadianbisma@unesa.ac.id
}

\begin{abstract}
E-Government terbukti mampu meningkatkan kualitas layanan public dan kepercayaan masyarakat terhadap pemerintah. Namun masih rendahnya tingkat penerimaan dan pemanfaatan layanan e-government pada negara berkembang. Pehahaman masyarakat terhadap egovernment belum dapat menjamin bahwa masyarakat bersedia menggunakannya. Sehingga petensi kerugian dalam investasi egovernment akan muncul. Penelitian ini berusaha menemukan factor yang mempengaruhi individu pengguna untuk meningkatkan layanan egovernment terutama jenis layanan transaksi yang disediakan oleh pemerintah. Penelitian ini menggunakan metode SEM-PLS yang melibatkan 93 responden dan menghasilkan faktor social norm (norma social) yang mempengaruhi penggunaan egovernment jenis layanan transaksi.
\end{abstract}

Kata Kunci-Mobile Learning, pengaruh, perguruan tinggi.

\section{Pendahuluan}

Perkembangan egoverment di saat ini sedang marak, hamper seluruh pemerintah daerah di Indonesia berusaha menerapkan egovernment untuk meningkatan efektifitas, transparansi , kualitas kerja, efisiensi administrasi layanan public, memperluas jangkauan layanan pemerintah, meningkatakan kepercayaan masyarakat kepada pemerintah.[1] Saat ini banyak pemerintah daerah membangun IT dan website untuk memberikan informasi kepada public.

Kenyataan di lapangan sebagian besar inisiatif layanan egovernment di negara berkembang tidak dimanfaatkan secara luas oleh masyarakat. Pemerintah daerah berharap masyarakat dapat meningkatkan partisipasi kepada egovernment terutama pada layanan transaksi. Rendahnya tingkat adopsi layanan egovernment ini menjadi masalah yang penting, accnture (2003) menyatakan bahwa manfaat egovernemt ditentukan oleh banyak dan seberapa maksimal sebuah layanan egovernment digunakan oleh masyarakat.

Beberapa factor yang menyebabkan kegagalan egovernment di negara berkembang dikarenakan beberapa factor antara lain desain sistem yang tidak sesuai dengan kondisi actual pada negara tersebut [2] Di Indonesia indiatif pembangunan sistem layanan egoverment hamper seluruhnya bersidat top-down, dan seluruh inisiatif pembangunan berasal dari pemerintah belum melibatkan peran serta masyarakat. Selain itu kurangnya sosialisasi dan kurangnya pemahaman alur yang digunakan di birokrasi pemerintah menjadi salah satu penyebab utama rendahnya tingkat penerimaan layanan transaksi layanan egovernment.

Sistem e-government dikelompokkan berdasarkan level interaksi pengguna aplikasi e- government. Level interaksi adalah pembagian kelompok pengguna sistem e-government. Level interaksi berdasarkan tingkat kompleksitas pengembangan dan fasilitas yang disediakan untuk melayani masyarakat antara lain level informasi, level interaksi, level komunikasi, dan level integrase (Baum \& Di Maio, 2000). Namun penelitian ini berfokus pada layanan transaksi, dimana e-government digunakan sebagai sarana untuk bertransaksi antara pemerintah dengan masyarakat sebagai pengguna layanan.

Penelitian terdahulu di Taiwan terhadap adopsi penerimaan e-government pada kasus pengajuan dan pembayaran pajak menyarankan kepada pemerintah untuk meningkatkan perceived usefulness, perceived ease of use, trust, compatibility, external influence, interpersonal influence, self-efficacy, dan facilitating condition sebagai indicator untuk meningkatkan layanan pemerintahan online [3] . Penelitian lain mengenai penilaian adopsi masyarakat pada egoverment di Gambia dan menghasilkan bahwa faktor yang memperngaruhi masyarakat Gambia dalam mengadopsi e-government adalah kualitas sistem informasi, kualitas informasi, perceived usefulness, dan perceived easy of use [4].

Desain sistem dan manajemen layanan e- government harus menyesuaikan dengan karakteristik dan kebutuhan masyarakat. Pemerintah wajib mendesain sistem e- government dengan memahami mengapa pengguna bersedia menggunakan sistem e-government dan mengapa sebagian besar masyarakat yang lain tidak bersedia atau belum memanfaatkannya. Serta mengetahui bagaimana masyarakat berinteraksi dengan sistem e-government selama ini. Sehingga dapat diketahui faktor apakah yang mempengaruhi dalam penerimaan user terhadap aplikasi e-government?. Pengetahuan ini sebagai landasan pengembangan dan manajemen layanan e-government yang dapat diterima masyarakat dan merupakan latar belakang penelitian ini.

\section{LITERATUR REVIEW}

\section{A. E-Government}

Kementrian komunikasi dan informatika mendefinisikan egovernment sebagai "Pemanfaatan teknologi informasi dan komunikasi dalam proses pemerintahan untuk meningkatkan efisiensi, efektivitas, transparansi, dan akuntabilitas penyelenggaraan Pemerintahan". Tujuan dari e-government merupakan perpaduan dari kumpulan TIK, sehingga dengan perkembangan teknologi membuat suatu koneksi digital yaitu :1) E- Government anak menghubungan antar departemen. 2) Menghubungkan antara pemerintah dan masyarakat. 3) Menghubungkan antara pemerintah dan bisnis. 4) Menghubungkan antara komunitas, social dan perkembangan ekonomi [2].

Di Indonesia, strategi implementasi e-government yang dilakukan oleh kemenkominfo untuk meningkatkan kualitas egovernment berfokus pada empat aspek antara lain : peraturan dan kebijakan; organisasi dan lembaga; aplikasi; dan 
infrastruktur. Salah satu point pada aspek tersbut adalah pada aspek aplikasi dengan mengembangkan aplikasi back office dan front office yang berorientasi G2B,G2C dan G2G. (Firmansyah Lubis (Direktur e-Government Kementerian Komunikasi dan Informatika RI), 2013). Posisi partisipasi egovernmet di Indonesia berdasarkan pada survey yang dilakukan oleh PBB pada tahun 2016 berada pada level Middle dari 4 level yang disediakan antara lain very high, high, midle dan low. Sedangkan level Indonesia mendapat peringkat ke 116 EGDI, turun 10 peringkat dibandingkan tahun 2014 yang menduduki peringkat ke 106 .

\section{B. Faktor Adopsi E-Government}

Berbagai macam faktor yang mempengaruhi individu, pikiran atau prilaku dalam memutuskan untuk menggunakan egovernment. Teori TPB menyatakan bahwa perilaku manusia terhadap teknologi dipengaruhi oleh tingkat keyakinan seseorang untuk menggunakan teknologi. Tingkat keyakinan tersebut merupakan salah satu faktor psikologis yang ada di balik tindakan individu, pikiran atau perilaku untuk memutuskan sesuatu hal seperti menggunakan atau tidak layanan e-government [5] Dengan memahami faktor psikologi, peneliti, pemerintah dapat mengukur tingkat penerimaan layanan e-government, mengevaluasi sistem dan layanan berdasarkan pengguna dan membuat strategi dalam meningkatkan kualitas layanan terhadap pengguna.

Penelitian mengenai Faktor psikologis pengguna egovernment menunjukkan bahwa sikap individu terhadap penggunaan (attitude towards use), tekanan sosial, persepsi terhadap layanan, teknologi, dan penyedia layanan (pemerintah) dapat mempengaruhi penerimaan layanan e- government .

Penelitian yang mengadopsi TAM dan UTAUT telah memverivikasi bahwa Perceived usefulness (atau performance expectancy) dan perceived ease of use (atau effort expectancy) memiliki pengaruh besar pada niat untuk menggunakan atau tidak menggunakan layanan e-government. TAM dipilih karena popularitasnya sedangkan UTAUT yang dikembangkan dari delapan model lain. Namun TAM dan UTAUT dikembangkan untuk penerimaan pengguna teknologi informasi dalam konteks organisasi kerja. Sedangkan eGovernement adalah konteks kehidupan sehari- hari. Dengan demikian perceived usefulness yang dirasa dari layanan egovernment mungkin berhubungan dengan sejauh mana layanan memenuhi kebutuhan sehari-hari dari warga Negara dan meningkatkan kinerja. Keuntungan lain adalah dapat mengurangi biaya dan efisiensi waktu dan kemudahan mengakses pelayanan publik dengan menggunakan egovernment.

Persepsi lain yang berperan penting dalam mempengaruhi penerimaan pengguna terhadap layanan e-government adalah resiko yang dirasakan (Perceived risk ) dan kepercayaan ( Trust ) [6] Penelitian lain menunjukan bahwa keamanan, privacy, ketidakpastian, dan resiko adalah faktor utama dalam mempengaruhi penerimaan pengguna [7], [8]. Belanger, Hiller, dan Smith (2002) menemukan bahwa kepuasan (pleasure), privacy, keamanan dan fitur website terkait dengan kepercayaan yang dirasakan (Perceived risk ). Penilaian dalam e-government menemukan bahwa ketidakpastian (uncertainty), keamanan, privasi, dan resiko adalah yang mendahului sebelum muncuknya perasaan percaya. (Al-Adawi et al, 2005; Balasubramanian, Konana, \& Menon, 2003; Induk et al, 2005 , Soat, 2003).

Dalam e-government warga (pengguna) mengisikan informasi mengenai identitas kedalam sistem e-government ketika berinteraksi dengan e-government sehingga pengguna egovernment seringkali merasa kurangnya privacy. Selama interaksi dengan situs web, pelanggan dapat merasakan ada resiko berkurangnya privasi (Parasuraman et al., 2005). Jadi, privasi yang dirasakan (perceived privacy) juga terkait dengan kepercayaan pengguna di web, yang pada akhirnya menunjukkan kepercayaan. Mempercayai web dapat meningkatkan dirasakan privasi perasaan pelanggan selama interaksi dalam e-Gov (Kemp, 2000).

Dalam layanan transaksi terdapat penelitian terdahulu dengan objek penelitian Pengisian pajak secara online dan sistem pembayaran di Taiwan yang mengusulkan sebuah model yang mampu menjelaskan varian cukup tinggi (72\%) dalam niat untuk menggunakan layanan e- government bila dibandingkan dengan penelitian terdahulunya. Model yang diusulkan menunjukkan bahwa niat untuk menggunakan layanan e-government ditentukan oleh tiga konstruks utama, antara lain : perilaku (attitude), norma subjektif (subjective norm), dan persepsi pengendalian perilaku (perceived behavior control) [9].

Dalam layanan transaksi dengan objek penelitian Pengisian pajak secara online dan sistem pembayaran di Taiwan yang mengusulkan sebuah model yang mampu menjelaskan varian cukup tinggi ( $72 \%$ ) dalam niat untuk menggunakan layanan egovernment bila dibandingkan dengan penelitian terdahulunya. Model yang diusulkan adalah menggunakan tiga konstruk utama antara lain perilaku (attitude), norma subjektif (subjective norm), dan persepsi pengendalian perilaku (perceived behavior control) [9] .

\section{Model Riset dan Hipotesis}

Model yang digunakan pada penelilitian ini diadosi dari model DTPB dengan menggunakan pendekatan model egovernment milik Hung, Chang, \& Yu ( 2006) yang juga mengadopsi DTPB. Keterbaruan dari model penelitian ini dengan menambahkan variabel baru yang didapatkan dari wawancara dan studi literatur yang telah dilakukan pada bab sebelumnya antara lain Perceived Quality of information system, perceived quality of the information dan perceived image. Pada penelitian ini juga merekomendasikan variabel baru yang bebeda dengan milik Hung, Chang, \& Yu ( 2006) . Variabel baru yang tidak terdapat pada model milik Hung, Chang, \& Yu ( 2006) pada model penelitihan ini dikategorikan sebagai variabel yang mempengaruhi sikap atau perilaku dalam penggunaan e-government. sehingga model riset pada penelitian ini menghasilkan model modifikasi DTPB Gambar model riset dapat dilihat pada gambar 1 


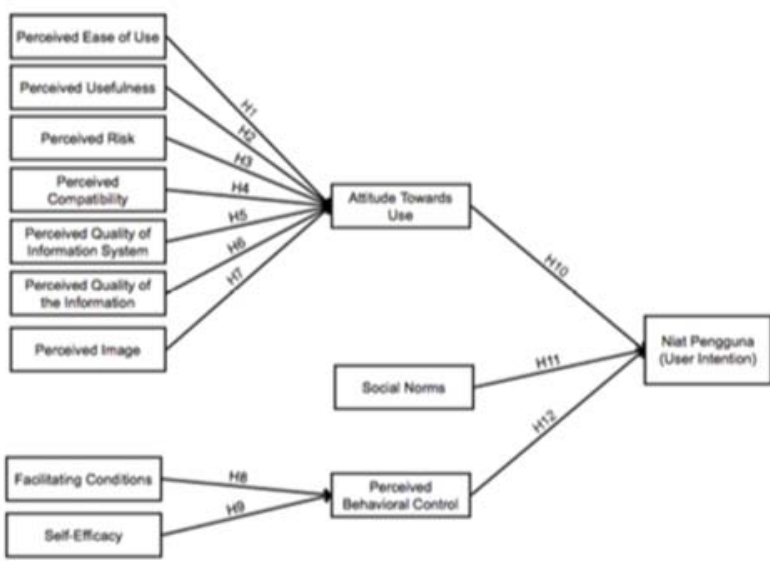

Gambar 1 Model Riset

\section{METODOLOGI}

Penelitian ini melibatkan responden yang merupakan pengguna layanan pemerintahan secara online yang tersebar di tiga kota di jawa timur yaitu Kota Surabaya, Kota Malang, dan Kabupaten Sidoarjo. Responden adalah masyarakat umum yang menggunakan layanan pemerintah secara online (egovernment). Beberapa responden juga mewakili peruntukan pribadi dan bisnis.

\section{A. Analisis dan pembahasan}

Total responden yang didapatkan adalah sebanyak 268 responden dan responden yang menggunakan layanan komunikasi 93 responden

\begin{tabular}{|c|c|c|}
\hline Variabel & $\begin{array}{c}\text { Jumlah } \\
\text { Responden }\end{array}$ & persentase \\
\hline 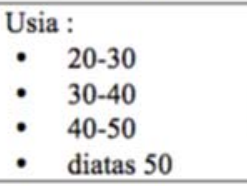 & $\begin{array}{l}179 \\
57 \\
25 \\
7 \\
\end{array}$ & $\begin{array}{l}67 \% \\
21 \% \\
9 \% \\
3 \% \\
\end{array}$ \\
\hline Variabel & $\begin{array}{c}\text { Jumlah } \\
\text { Responden }\end{array}$ & persentase \\
\hline $\begin{array}{l}\text { Jenis Kelamin : } \\
\text { - } \quad \text { Laki-laki } \\
\text { - } \quad \text { Perempuan }\end{array}$ & $\begin{array}{l}174 \\
94\end{array}$ & $\begin{array}{l}65 \% \\
35 \%\end{array}$ \\
\hline \begin{tabular}{ll}
\multicolumn{3}{l}{ Peruntukan : } & \\
- & Pribadi \\
- & Bisnis \\
- & Pribadi \& \\
& Bisnis
\end{tabular} & $\begin{array}{l}189 \\
46 \\
33\end{array}$ & $\begin{array}{l}71 \% \\
17 \% \\
12 \%\end{array}$ \\
\hline
\end{tabular}

\section{B. Pengolahan dan Pengujian Data}

Pengolahan data kuesioner sekaligus uji validitas dan reliabilitas datanya, menggunakan metode Partial Least Square dengan alat bantu SmartPLS. Data kuesioner dimasukkan ke dalam rancangan model pada SmartPLS yang meliputi model pengukuran dan model struktural. Model kemudian dikalkulasi dan hasilnya pada gambar 3

\section{Pengujian Model Pengukuran}

Model pengukuran merupakan pola hubungan antara indikator dengan variabel yang diukurnya (variabel laten).

1) Indikator validitas : nilai faktor loading lebih besar 0.5 dan nilai t_statistic $\geq 1.96$. Jika nilai factor loading lebih besar 0.5 maka korelasi tersebut valid. Nilai t-statistic yang dianggap signifikan adalah nilai $\geq 1.96$. Indikator yang berada di bawah nilai 0.5 , atau indikator yang memiliki factor loading lebih dari 0.5 namun nilai t- statistic kurang dari 1.96 akan dihilangkan dan akan diulang pengujiannya.

2) Reliabilitas Data : Pemeriksaan selanjutnya dari adalah reliabilitas konstrak dengan melihat nilai composite reliability (CR) atau nilai croncbach's alpha (CA). Indikator dikatakan reliable ketika nilai composite reliability (CR) atau croncbach's alpha (CA) lebih dari ( $\geq) 0.70$ [10].

3) Pengujian berikutnya yang masih merupakan convergent validity adalah melihat nilai Average Variance Extracted (AVE) yang merupakan besarnya varian atau keberagaman variabel manives yang dapat dikandung oleh konstrak laten. Sehingga semakin besar varian atau keberagaman variabel manifest yang dikandung konstrak laten, maka semakin besar representasi variabel manifest terhadap konstrak latennya [10].. Nilai AVE minimal 0.5 menunjukan ukuran convergent validity yang baik

4) Evaluasi discriminant validity dilakukan dengan cara melihat nilai cross loading. Yaitu dengan setiap indikator yang mengukur konstrak haruslah berkorelasi lebih tinggi dengan konstraknya dibandingkan dengan konstrak lain.

\section{Pengujian Model Struktural}

Model struktural (inner model) merupakan pola hubungan antarvariabel penelitian. Signifikasi hubungan antara konstrak dan dapat dilihat dari nilai koefisien jalur (path coefficient). Tanda pada path coefficient harus sesuai dengan teori yang dihipotesiskan. Untuk menilai signifikasi path coefficient dapat dilihat dari nilai t test (critical ratio) pada proses bootstrapping (resampling method). Jika nilai t-statistic $\geq 1.96$ maka dapat dikatakan hubungannya signifikan. Pengujian berikutnya 
Tabel 1 Nilai Koefisien Hubungan Antar Variabel

\begin{tabular}{|ccccc|}
\hline Hipotesis & Hub. Variabel & Original Sample (O) & T Statistics & Kesimpulan \\
\hline H10 & AT -> UI & 0.164347 & 1.393795 & Tidak signifikan \\
\hline H8 & FC -> PBC & -0.293571 & 4.78453 & Signifikan \\
\hline H6 & IQ - - AT & 0.184918 & 1.190298 & Tidak signifikan \\
\hline H12 & PBC - - UI & 0.040249 & 0.401628 & Tidak signifikan \\
\hline H4 & PC -> AT & 0.203359 & 1.677698 & Tidak signifikan \\
\hline H1 & PEOU - AT & 0.362858 & 2.989365 & Signifikan \\
\hline H7 & PI -> AT & -0.08274 & 0.523348 & Tidak signifikan \\
\hline H3 & PR -> AT & -0.030235 & 0.329577 & Tidak signifikan \\
\hline H2 & PU -> AT & 0.078681 & 0.434158 & Tidak signifikan \\
\hline H5 & QIS -> AT & -0.014111 & 0.124261 & Tidak signifikan \\
\hline H9 & SE - PBC & 0.448736 & 6.148369 & Signifikan \\
\hline H11 & SN -> UI & 0.330521 & 3.418343 & Signifikan \\
\hline
\end{tabular}

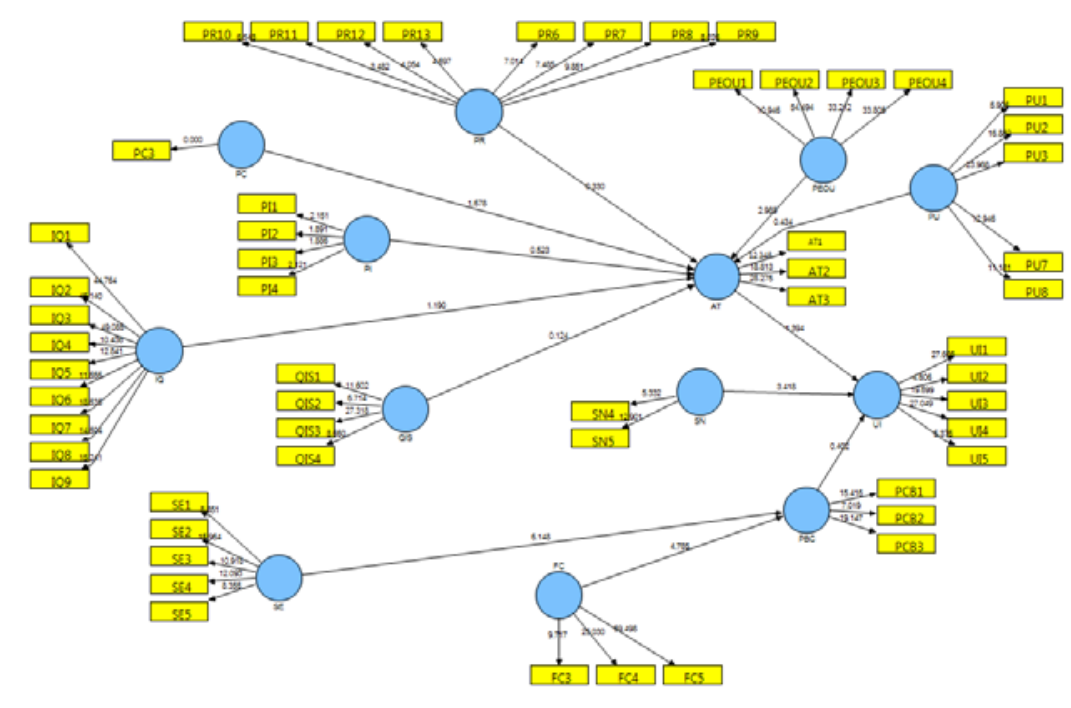

Gambar 2 Hasil Kalkulasi Model dengan SmartPls

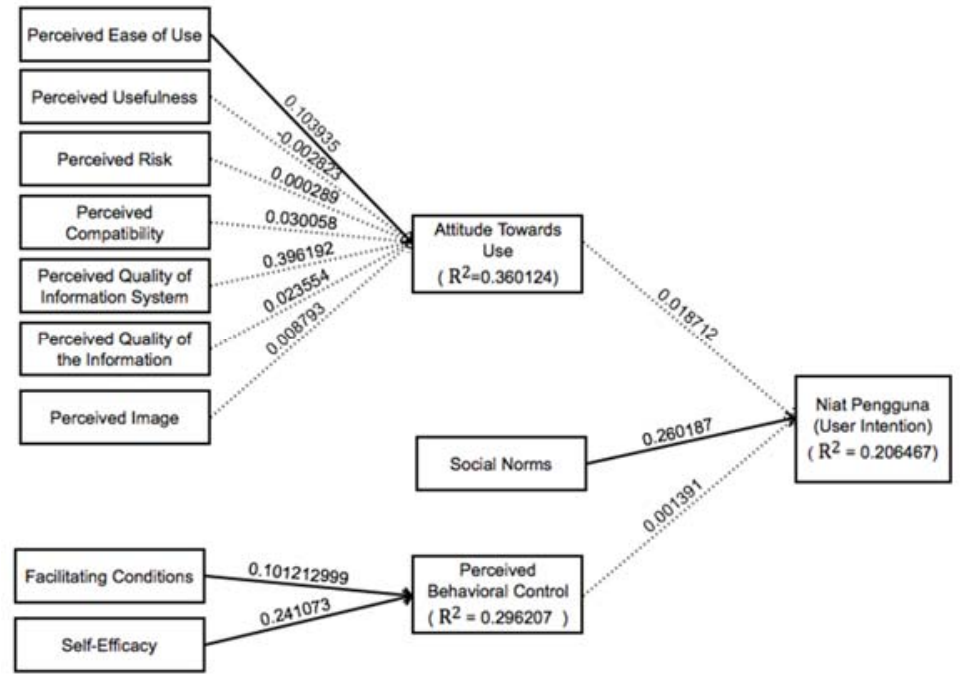

Gambar 3 Hipotesa Penelitian 
adalah koefisiensi determinasi (Nilai R2) : menjelaskan mengenai besarnya variability variabel endogen yang mampu dijelaskan oleh variabel endogen [10]. Nilai R2 diklasifikasikan menjadi tiga yaitu $0.67=$ substansial, $0.33=$ moderat, dan 0.19 = lemah. Nilai R2 variabel AT adalah 0.360134 , nilai R2 variabel PBC adalah 0.296207, dan R2 variabel UI adalah 0.206467 . lalu dilanjutkan untuk mencari nilai $\mathrm{f}^{2}$ yang menjelaskan pengaruh variable tertentu terhadap variable dependennya.

\section{E. Pengujian Model Struktural}

Pengujian berikutnya untuk melakukan validasi model adalah dengan melihat nilai goodness of fit (Gof). Gof merupakan ukuran tunggal yang digunakan untuk memvalidasi performa gabungan antara model pengukuran dan model structural. Nilai Gof diperoleh dari average communalities index dikalikan dengan rata-rata nilai R2 . (Vinzi, 2010). Nilai Gof antara 0 - 1 dengan interpretasi nilai adalah 0.1 (Gof Kecil), 0.25 (Gof Moderat), 0.36 (Gof Besar) semakin besar nilai Gof maka semakin fit/sesuai dalam menggambarkan sample penelitian.

\section{HASIL ANALISA}

\section{A. Analisa Model Pengukuran}

Hasil pengukuran merupakan pola hubungan antar variabel dengan variabel yang diukurnya (variabel laten) hasilnya semua indikator mempunyai nilai faktor loading $>0.5$ dan hampir semua indikator mempunyai nilai $t$-statistic $\geq$ 1.96.Taraf nyata $(\alpha)$ dalam penelitian ini adalah 0.05 dan nilainya di dalam tabel distribusi normal adalah 1.96, artinya suatu hubungan disebut ada pengaruh apabila t-statistic $\geq 1.96$ (Walpole dkk, 1995). Jadi tingkat keyakinan penelitian ini adalah $95 \%(1-\alpha)$.

Penelitian ini menggunakan nilai CA untuk mengukur reliabilitas datanya. Terdapat 13 variabel yang diuji yang memiliki varian indikator cukup besar (nilai AVE $\geq 0.5$ ) hanya variable PR yang mempunyai nilai AVE kurang dari 0.5 hal ini menunjukan kurangnya ragam varian indikator yang dikandungnya. Semua indikator memiliki validitas diskriminan yang baik (nilai cross faktor menunjukkan semua indikator berkorelasi dengan konstrak induknya disbanding dengan konstrak lain).

\section{B. Analisa Model Struktural}

Evaluasi model structural menunjukkan pola hubungan antar variabel. Analisis terhadap model structural merupakan analisis terhadap pola hubungan antar variabel yang merupakan analisis hipotesa penelitian. Pengujian ini menggunakan nilai koefisien jalur dan t-statistik yang dapat mewakili hipotesis penelitian. Koefisien jalur menunjukkan hubungan antar variabel berkorelasi secara positif atau negative. Sedangkan t-statistic menunjukkan hubungan variabel tersebut signifikan atau tidak.
Hipotesis diterima jika hubungan antar variabel berkorelasi positif dan signifikan. Hasil dapat dilihat di Tabel I.

Berdasar tabel diatas tampak sebagian besar hubungan antar variabel bernilai positif atau berkorelasi secara positif, namun tidak signifikan pengaruhnya (memiliki nilai t-statistic kurang dari 1.96). Terdapat dua nilai dari hubungan antar variabel yang berkorelasi positif dan memiliki nilai t-statistic lebih dari 1.96. sehingga nilai tersebut juga mewakili hipotesis yang diterima.

Hubungan jalur yang signifikan adalah Kondisi Fasilitas (facititating condition) yang signifikan terhadap persepsi kontrol perilaku (percerived behavior control) (Hipotesis 8), persepsi kemudahan penggunaan (perceived ease of use) yang signifikan terhadap sikap (hipotesis 1), kepercayadirian (Selfefficacy) yang signifikan terhadap persepsi kontrol perilaku (percerived behavior control) (Hipotesis 9) dan norma sosial (Social Norm) yang berpengaruh positif terhadap niat penggunaan (hipotesis 11). Namun hipotesis 8 , hipotesis dan hipotesis 9 tidak dapat secara langsung mempengaruhi niat penggunaan karena persepsi kontrol perilaku (percerived behavior control) (hipotesis 12) dan sikap (hipotesis 10) penggunaan tidak secara positif atau tidak signifikan mempengaruhi niat penggunaan

Dengan melihat nilai Effect Size pada tabel 5.21 menunjukan nilai Effect Size masing-masing variabel dan mayoritas berada pada level kecil, kecuali nilai Effect Size pada variabel SE yang nilainya kecil menuju sedang. hal ini mengacu pada kriteria yang dikemukakan Jacob Cohen yang membagi Effect Size $f^{2}$ ke dalam tiga kriteria: 0,02 (kecil), 0,15 (sedang) dan 0,35 (besar)

\section{Analisa Model Gabungan}

Analisis Selanjutnya dengan melihat nilai $\mathrm{R}^{2}$ terhadap konstrak variabel. Berdasarkan tabel 5.11 dapat diketahui persepsi kemudanan (perceived ease of use) mampu menjelaskan variabel sikap (attitude) sebesar 36.01\%, Kondisi Fasilitas (facititating condition) dan kepercayadirian (Selfefficacy) mampu menjelaskan variabel Persepsi kontrol perilaku (percerived behavior control) sebesar 29.62\% dan yang terakhir norma sosial (Social Norm) mampu menjelaskan variabel niat penggunaan e-government sebesar $20.69 \%$. menurut Chin (1998) Nilai tersebut dikategorikan sebagai nilai kecil. Selanjutnya setelah mendapatkan nilai rata-rata dari $\mathrm{R}^{2}$ dan nilai dari Communalities dapat diketahui nilai Gof. Nilai Gof sebesar 0.4360 dapat dikategorikan sebagai Gof Besar, sehingga dapat dinyatakan model telah sesuai secara substansial dalam mempresentasikan hasil penelitian [1]

\section{KESIMPULAN}

Pada tabel 1 menunjukkan bahwa hubungan antara SN dengan UI adalah signifikan dengan T-statistik sebesar 3.418343 ( $>1.96$ ). nilai original sample adalah positif yaitu sebesar 0.330521 yang menunjukan bahwa arah hubungan antara SN dengan UI adalah positif. Dengan demikian hipotesis H11 dalam penelitian ini menyatakan bahwa 'Norma Sosial (social norm) memiliki hubungan positif terhadap niat 
penggunaan e-government' diterima. Norma sosial (Social Norm) yang berpengaruh positif terhadap niat penggunaan (hipotesis 11)

Dari penelitian ini menunjukan bahwa pengaruh dari orang lain (Social Norm) penting ketika menggunakan sebuah sistem seperti e-government. Hal ini sesuai dengan yang menyatakan bahwa pengaruh sosial memiliki dampak yang signifikan terhadap niat perilaku untuk menggunakan sistem [11], namun gupta, dkk tidak dapat membedakan pengaruh jenis kelamin terhadap pengaruh yang diberikan terhadap seseorang. Sehingga secara umum dalam penggunaaan e-government pengaruh sosial atau orang lain akan sangat diperlukan untuk meningkatkan penggunaan sistem e-government terutama pengaruh secara positif

\section{REFERENSI}

[1] B. Furuholt and F. Wahid, "E-government challenges and the role of political leadership in Indonesia: The case of Sragen," in Proceedings of the Annual Hawaii International Conference on System Sciences, 2008, pp. 1-10.

[2] R. Heeks, Implementing and Managing eGoverment, 1st ed. London, 2006.

[3] S.-Y. Hung, C.-M. Chang, and S.-R. Kuo, "User acceptance of mobile e-government services: An empirical study," Gov. Inf. Q., vol. 30, no. 1, pp. 33-44, Jan. 2013.

[4] F. Lin, S. S. Fofanah, and D. Liang, "Assessing citizen adoption of e-Government initiatives in Gambia: A validation of the technology acceptance model in information systems success," Gov. Inf. Q., vol. 28, no. 2, pp. 271-279, Apr. 2011.

[5] A. Bandura, "Self-efficacy: Toward a unifying theory of behavioral change.," Psychol. Rev., vol. 84, no. 2, pp. 191-215, 1977.

[6] M. Horst, M. Kuttschreuter, and J. M. Gutteling, "Perceived usefulness, personal experiences, risk perception and trust as determinants of adoption of e-government services in The Netherlands," Comput. Human Behav., vol. 23, no. 4, pp. 1838 1852, Jul. 2007.

[7] Z. Al-Adawi and S. Yousafzai, "CONCEPTUAL MODEL OF CITIZEN ADOPTION OF E-GOVERNMENT."

[8] M. A. Shareef, U. Kumar, V. Kumar, and Y. K. Dwivedi, "Identifying critical factors for adoption of e-government," Electron. Gov. an Int. J., vol. 6, no. 1, p. 70, 2009.

[9] S.-Y. Hung, C.-M. Chang, and T.-J. Yu, "Determinants of user acceptance of the e-Government services: The case of online tax filing and payment system," Gov. Inf. Q., vol. 23, no. 1, pp. 97-122, Jan. 2006

[10] H. Yamin, S., \& Kurniawan, Generasi Baru Mengolah Data Penelitian dengan Partial Least Square Path Modeling. Jakarta, Indonesia: Salemba Infotek., 2011.

[11] B. Gupta, S. Dasgupta, and A. Gupta, "Adoption of ICT in a government organization in a developing country: An empirical study," J. Strateg. Inf. Syst., vol. 17, no. 2, pp. 140-154, Jun. 2008. 